\title{
The Dynamics of the Community of Kampung Batik Semarang in Overcoming Slumness
}

\author{
Titiek Suliyati ${ }^{1,}$, Dewi Yuliati $^{1}$, Slamet Subekti $^{1}$, Tri Handayani ${ }^{1}$ \\ ${ }^{1}$ Department of History, Faculty of Humanities, Diponegoro University
}

\begin{abstract}
At the beginning of its growth, Kampung Batik developed rapidly as a center of batik production and as a residence for residents of Semarang and its surroundings. Kampung Batik then became a very crowded, slum village and became a hotbed of crime). The Kampung Batik in 2016 was designated as a Thematic Village by the Mayor of Semarang. This has aroused public awareness to improve the village, both physically and socially. Changes in Kampung Batik from slum villages to clean and beautiful villages deserve to be studied because of the large role of the community in managing the village environment. The problem examined in this article is how community management in Kampung Batik is carried out so that it can transform slums into beautiful villages. Because the study of this article discusses the process of change and development of Kampung Batik, the method used is the historical method, the stages of which are heuristics (source collection), criticism, interpretation, and writing facts). The conclusion is that the Semarang City Government program to create a Thematic Village has a positive value. Kampung Batik, which has been arranged, has become one of the tourist destinations in Semarang.
\end{abstract}

Keywords: Kampung Batik; Thematic Village; Handling; Slums.

\section{Introduction}

Since the $20^{\text {th }}$, century there has been a very high concentration of population in large cities in third world countries, which has led to problems of unemployment, underemployment, and so on. These are poor people in urban areas who later become the burden of the city [1]. These urban poor live in villages that thrive in urban areas, including the city of Semarang.

Semarang is one of the big cities in Indonesia with residents from diverse regions, livelihoods, and ethnicities. At the beginning of its establishment, there have been traditional villages that still exist until now. According to the Global Report on Human Settlements, the urban poor in developing countries are reflected in the number of urban residents living in slum area, which amounts to $43 \%$ [2]. This also happened in Indonesia big cities including Semarang.

To date, there are 16 sub-districts and 177 villages/urban villages in Semarang. These 177 villages/urban villages, there are many villages with poor condition and have their own characteristics.

According to [3], village as a place to live that was built independently can exist because the population has the ability to maintain human values in the complexity of modern urban life. [4, 5] defined village as a very complex community dynamics, starting from constructing houses independently, controlling the environment, and cooperating in the form of mutual assistance to build a prosperous life. In general, it can be said that urban village is a part of the city which has the characteristics of high population, inadequate infrastructure, and dynamics and social changes caused by urban development. Widjajanti [6] stated that the character of city is formed from urban village as settlement.

Along with the development of village which is increasingly populous and difficult to control, attention to village by urban policyholders and experts in settlements began to emerge. Village structuring programs related to sanitation planning, environment, and community empowerment, etc. began to be applied in urban villages.

Urban villages in Indonesia including in Semarang have distinctive features and uniqueness such as holding on to village characteristics and culture, which shows intimacy of the family [7]. Another feature is the condition of urban villages that are slum, crowded, unorganized, and having inadequate facilities and infrastructures. Slums are uninhabitable settlements because they do not meet the requirements for housing both technically and non-technically. Slums are different from squatter. Slum is a settlement whose status is legal but the condition is not feasible as a place to live. Squatter is an illegal settlement in open spaces. Squatter is on land owned by another party such as state land, individual land, legal entity land or foundation land [8]. In Indonesia, there are generally two types of slum

\footnotetext{
*Corresponding author: suliyati.titiek@gmail.com
} 
settlements, namely slums caused by the aging process of buildings and due to compaction processes The process of building aging is a process of decreasing the quality of buildings because the age of a building that is old, fragile and bad, thus causing a slum environment. The process of compaction of buildings is due to population growth. Increased shelter needs to cause no more vacant land, so the house looks jostling and slum [9].

In handling poverty in urban areas, Mayor of Semarang, Hendrar Prihadi proposed several excellent programs. One of them is Thematic Village. Thematic Village is an area under the administration of urban village that shows identity/meaning of a potential community or area that is appointed and highlighted on the results of a shared agreement. The purpose of Thematic Village program is to reduce poverty and unemployment, increasing the quality of the settlements, elevating local wisdom and managing potentials and increasing tourist destinations [10].

Until 2017, there was a movement to handle urban slums performed by the Mayor of Semarang. This movement did not only make improvement, but also facilitate several innovations which eventually made the area of slum to be a clean, beautiful, organized, and attractive area.

Thematic Village Program is also a form of community empowerment by Semarang City Government to increase the capacity of village community from instilling awareness in maintaining their neighborhood, provide insight into knowledge, and provide basic skills. It allows them to take part in development, as well as increase intellectual capacity and skills so that initiatives and abilities are foster to deliver self-reliance.

From 32 urban villages of Thematic Villages, Kampung Batik includes in the earliest designated village as Batik Thematic Village. After designated as a Thematic Village, Kampung Batik has undergone significant changes. The village, formerly known as a slum area and criminal hideout, is now known as a beautiful village and has become one of tourist destinations in Semarang City. Stimulant from the City Government is in line with community participation in village management by relying on community-based management which has produced encouraging results. Currently, Kampung Batik has morphed into a beautiful village. Besides, they also promote batik with specific motifs of Semarang.

\section{Study Area}

Geographical Location and Environment of Kampung Batik Semarang. Kampung Batik is located in Rejomulyo village, East Semarang sub-district. The area of Kampung Batik is divided into 2 (two) RW namely RW 01 and RW 02. Boundaries of Kampung Batik are as follows:

- North is bordered with Kemijen Urban Village

- East is bordered with Mlatibaru Urban Village

- South is bordered with Bugangan Urban Village
- West is bordered with Semarang Tengah Sub-District The area of Kampung Batik consists of two RW, namely RW 01 and RW 02. RW 01 consists of 7 (seven) RT and RW 02 consists of 9 (nine) RT. The craft center and batik industry are in RW 02 . This can be seen from the number of batik shops in RW 02 which are 14 shops with 7 family batik artisans.

In RW 02, RT 04 took the initiative to create mural with Semarang historical themes and batik motifs. The uniqueness displayed by RT 04 made the residents call it "Kampoeng Djadoel". Therefore, actually, Kampoeng Djadoel represents.

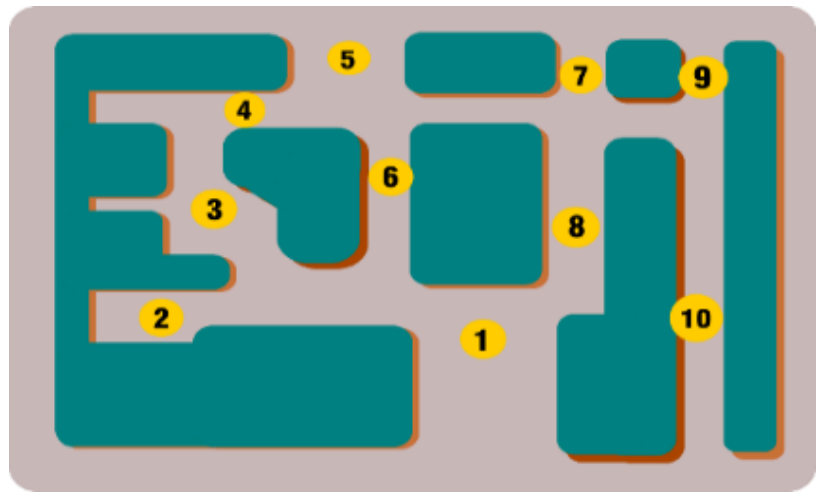

Fig. 1. Kampung Batik plan Information :

1. The entrance to the Kampung Batik

2. Kampung Batik Gedong

3. Kampung Batik Tengah/Kampoeng Djadoel

4. Kampung Batik Malang

5. Kampung Batik Gayam

6. Kampung Batik Krajan

7. Kampung Kubur Sari

8. Kampung Sari Batik II

9. Kampung Batik Krajan Baru

10. Kampung Batik Sari I

\section{Methodology}

In line with the problems and objectives of this research, the research method was descriptive qualitative method with historical and sociological approach [11]. Qualitative methods are used because this study seeks to uncover social problems written in detail [12]. This research is descriptive in nature to help the writer to factually describe the relationships between the instruments studied.

This descriptive qualitative method is intended to provide a better understanding of the process of formation and development of Thematic Villages in Semarang. Historical approach was used to collect, select, and critically examine historical sources to produce historical facts. Historical facts were then analyzed in a systematic description through cultural approach. The data sources in this research were obtained from books, articles, newspapers, and results of research which used historical descriptive analysis. It is an attempt to describe establishment and development 
process of Thematic Villages in Semarang. The books that are used as references are books relating to qualitative research, books on slum areas, books on environmental pollution, books on the history of Kampung Batik in Semarang, books about villages and so on. The article used as a reference included the Phenomenon of the Survival of Kampong Kuningan Amid the Development of the Mega Kuningan Business Area in Jakarta, From the Culture of the Poverty to the Inclusive Cities: Re-Framing Urban Policy and Politics, etc.

In addition, the data was obtained through interviews, field notes, photos, personal documents [13]. Interviews were conducted with 9 Batik villagers namely RT Chairperson, Chairperson of the Kampung Batik Community, batik artisans and community members who had been living in Kampung Batik for a long time.

After the data sources were collected, external and internal source criticism were performed to gain credibility and authenticity. Historical facts obtained were then interpreted according to the cultural approach. The last stage was historiography, which is writing the research results in the form of article.

\section{Environmental Change in Kampung Batik}

The impact of rapid development of Semarang Batik and in line with Regional Regulation No. 14 of 2011 by the Regional Government on the Establishment of Kampung Batik as a cultural reservation has quickly led Kampung Batik Semarang to improve and organize itself.

Before 2011 Batik Village could be categorized as a slum because there were very dense housing and dirty, poorly maintained and unsafe environments. Since being declared a cultural preserve in 2011 and as a Thematic Village in 2016, Kampung Batik has turned into a clean, safe and orderly village. This change was caused by public awareness, namely that after Kampung Batik was established as a Thematic Village there must be an increase in environmental quality. For this reason, routine environmental maintenance needs to be carried out with cleaning of gutters and yards, planting trees in pots, painting walls of houses and roads, disposing of garbage in its place, handling batik waste and so on. For handling batik waste, there are batik artisans who have made waste wells, which are then disposed of in the waste disposal center. Next year there are government efforts to help create tools for handling batik waste.

The organized condition of Kampung Batik attracts tourists both foreign and domestic to visit. The tourists are interested in observing Semarang batik production process in Kampung Batik. Batik produced by "Kampung Batik" artisans also develops motifs that support the sharpening of Semarang city identity. These motifs are inspired by ancient buildings, flora or fauna, and Semarang unique arts and culture, such as Blenduk Church, Kuntul, WarakNgendog. This tourist visit certainly enhances the economics of Kampung Batik community.

With the increasing popularity of Kampung Batik, one of the RTs, which is RT 04 tried to further enhance the image and popularity of Kampung Batik by making theirs into Kampoeng Djadoel.

Locals call it as Djadoel which stands for "djaman doeloe" (old period). Kampoeng Djadoel is different from the Kampung Batik which was already known to the public because the main concept of Kampoeng Djadoel was not in batik production, but in the effort to introduce Javanese and Semarang culture to the community. Kampoeng Djadoel residents also realized that in order to attract the interest of the community in visiting their villages, they also had to organize their village environment. The implication of the clean Kampoeng Djadoel is that the surrounding villages also try to organize and clean the environment so that it is not slum. The image as a Thematic Village can be maintained if all villagers participate in village management and arrangement

The emergence of Kampoeng Djadoel in 2016 was in line with the rise of Thematic Villages in Semarang. The residents of RT 04 RW 02 who are the members of Kampung Batik community took the initiative to improve their village. What has been performed by Kampoeng Djadoel residents is in accordance with [14] who stated that one of the creators of creative city is creative community. Communities are needed to help encouraging and to make creative space.

Landry [15] states that villages that are creative in their communities can easily adapt to changes in the environment and withstand all kinds of problems that occur to them. In addition, people who live in urban villages are potential that can be fostered to strengthen the city's image.

One of their creativities is painting mural on the walls and streets. Before the walls were drawn in a mural, the walls were cleaned first, painted and the environment cleaned of rubbish, so the murals looked beautiful. The main mural is themed with History of Semarang City, starting from ancient Mataram kingdom to the establishment of Semarang City by Ki Ageng Pandanaran. The mural also illustrates the process of Islamization in Semarang and arrival of Admiral Cheng Ho who made settlements around Gedong Batu. Then, it is continued with pictures of the occupation of Dutch Colonial Government and VOC, and Japanese occupation until Indonesian independence. The mural is painted using Wayang Beber model and combined with artistic batik paintings. It is about 2 meters high and 46 meters long. Besides the main mural, there is also mural with batik motifs, natural landscapes, and flora \& fauna decorations on the walls. The story displayed in the mural is information about the history of Semarang city that is easy to understand and interesting. To understand the mural story, there are usually residents who explain the pictures. This makes visitors to Kampoeng Djadoel understand the history of Semarang city briefly.

The success of Kampoeng Djadoel in making changes from slum villages to beautiful villages is inseparable from community participation. Participation is seen from its level of three, namely: (1) planning level, (2) implementation stage, and (3) utilization stage. The participation of the Kampoeng Djadoel community began with a plan led by Mr. Luwiyanto and the 
Chairperson of the RT then carried out socialization to the villagers. At the implementation level, the head of the RT and several community leaders invited residents to actively support the improvement of Kampoeng Djadoel. The main program of Kampoeng Djadoel is environmental cleanliness. A clean environment can be seen from no scattered garbage, dirty and smelly sewers, no flooding because water overflows from the gutter. Besides that, the environment becomes beautiful with ornamental plants along the road and yard. A clean environment also leads to better public health. Outbreaks of diseases such as Dengue Fever and other infectious diseases have declined.

In the end, when Kampoeng Djadoel was organized and could be utilized, the community enjoyed the results of their hard work, namely in the form of increasing income, a cleaner environment, and their villages were widely known. This was proven several times that Kampoeng Djadoel won the village cleaning competition at the village and city level.

To increase the attractiveness of KampoengJadoel, in addition to making murals, the community participated in road cleaning, sewer cleaning and the environment. The villagers worked together not only on labor but also on funds. So far there has been no financial assistance from the City Government or from the private sector. Funds to fix Kampoeng Djadoel are entirely borne by residents. Funds that come from community donations or from batik training, rent out old clothes and bicycles, are all managed by RTs and are used to build and improve villages. Because Kampoeng Djadoel is not a Thematic Village programmed by the City Government, KampoengJadoel did not get village management funds of Rp. $200,000,000$.

The neat and orderly condition of Kampoeng Djadoel has attracted many domestic and foreign tourists to visit the village. To increase the attractiveness of Kampoeng Djadoel, the Head of RT 04 RW 02, Dwi Christianto and Secretary of RT 04 RW 02, Luwiyanto together with the community have an initiative to sell batik produced by Kampung Batik and other regions (Interview with Luwiyanto and Dwi Christianto, October 19, 2018). In this village also sold handicrafts from the remains of batik cloth and also provided traditional clothes and ancient bicycles, which were rented for photos (interview with Afifah, March 8, 2019). The things mentioned above can be categorized as the initial steps of the 3R Program (Reduce, Reuse and Recycling), which are being promoted by the Semarang City Government. In addition, there are Semarang specialties sold in Kampoeng Djadoel. Even when there are visitors in Kampoeng Djadoel, are welcomed with traditional music and old songs (interview with Ida Parwati, Mach 9, 2019).

In addition, traditional clothing and old-fashioned bicycles are also available, which are rented for photos (interview with Eko Hariyanto, March 19, 2019). It also sells specialty foods of Semarang (interview with Christine, February 10, 2019). In fact, Kampoeng Djadoel visitors are welcomed with traditional music and song. Kampoeng Djadoel community independently worked on their village and conducted village planning (interview with Elisabet, March 19, 2019). The research results of [16] concluded that the social characteristics of village community are good relationship among neighborhood, mutual assistance, roles of community leaders, and roles of community organizations. The results of this research are also in accordance with the description of Kampung Batik Semarang characteristics, in which the characteristics can promote active participation and creativity of the community.

Since Kampoeng Djadoel becomes a tourist destination, the locals begin to think about what will be presented to the tourists. To capture the ideas from residents, Kampung Batik Association of Tourism Awareness Groups (Pokdarwis) was formed (interview with Fauzi, February 14, 2019). This community-based management has implications for harmony and mutual cooperation among villagers in solving environmental hygiene problems, environmental management and environmental health and security issues (interview with Iin Windhi Indah Tjahjani, February 10, 2019).

The management applied by Pokdarwis in carrying out its duties is community-based management. The community management is very flexible in its application, for example when there are problems that must be solved, the administrators can gather quickly at the agreed place and time (interview with Widodo, March 8, 2019). The basis of kinship, togetherness, harmony, and mutually helpful become the principle of village management. Thus, it is expected that the progress of village for shared interest can be achieved.

For future development, the managers of KampoengDjadoel have hopes of making 3-dimensional paintings on village roads, which aim to complete the atmosphere of Kampoeng Djadoel with historical visualization. The focus of Kampoeng Djadhoel is not batik production, but the frame of batik painting. However, batik cloth will also be produced. Another hope is the compilation of a book on the history of Semarang City so that people who visit Kampoeng Djadoel are more familiar with the history of the city of Semarang.

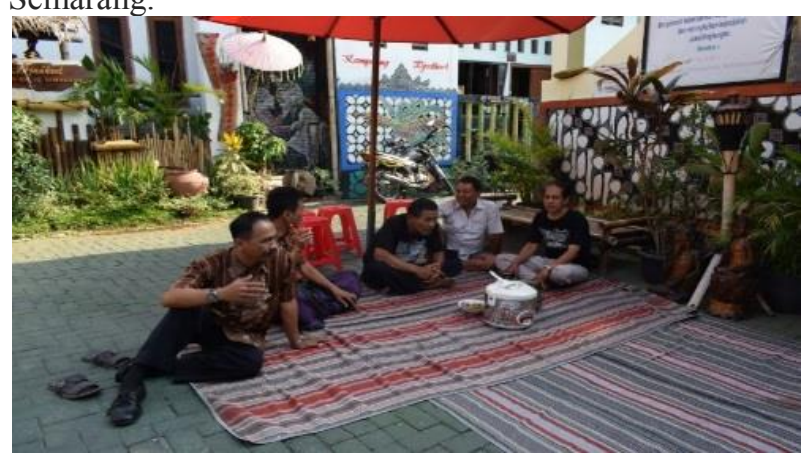

Fig. 2. Kampoeng Djadoel's community members held a discussion 


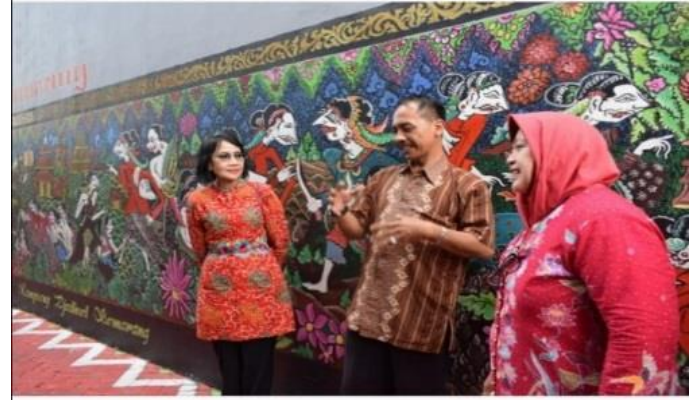

Fig. 3. Mural Paintings in Kampoeng Djadoel

\section{Conclusion}

Today, KampoengDjadoel is a tourist destination available for both people of Semarang and outside of Semarang and also foreign tourists. It certainly brings dynamics for Kampoeng Djadoel to be a beautiful, clean, and safe village. Slum, dark and dangerous conditions are ceased. The efforts and hard work of Semarang community, in this case, the people of Kampung Batik and Kampung Djadoel, need to be appreciated. They try to show their existence and identity as a good Semarang society in their own way.

The results of this study indicate that social capital that has been fostered from the start, such as the close relationship between citizens, mutual cooperation and concern for the environment, has encouraged community participation in managing their villages. The role of the community in managing the village shows the slum conditions that have adorned the face of the village, starting to change with beauty. Arrangement of roads, sewers, waste management, and waste began to show results, namely the village looks beautiful and healthy

The role of the City Government in establishing Thematic Village program needs to be appreciated since it has aroused great enthusiasm as well as community participation in village planning. It is expected that in the near future, slums in Semarang can be reduced or even eliminated. Therefore, there must be a continuous synergy between the Government and the community to create an urban environment with clean and beautiful villages.

\section{References}

1. P. Basundoro, Merebut Ruang Kota: Aksi Rakyat Miskin Kota Surabaya1900-1960-an, Tangerang: Marjin Kiri (2013)

2. Jo. Beall, From the Culture of Poverty to Inclusive Cities: Re-Framing Urban Policy and Politics, Journal of International Development. 12 (6); ABI/INFORM Global (2000).

3. B.A. Putra, The Survival Phenomenon of Kampong Kuningan Amidst the Development of Mega Kuningan Business-area in Jakarta, International Journal of Scientific \& Engineering Research 4, 1-6 (2013)
4. Setiawan, Penanggulangan Pencemaran Lingkungan. Jakarta: RinekaCipta (2010)

5. Bakti Setiawan, Kampung Kota dan Kota Kampung. Potret Tujuh Kampung di Kota Jogja, Yogyakarta: Pusat Studi Lingkungan Hidup Universitas Gajah Mada (2010)

6. W.W. Widjajanti, Menciptakan Kampung Kota sebagai Hunian yang Ramah dalam Konteks Urban di Surabaya, Jurnal Institut TeknologiAdhi Tama Surabaya 4 (2013)

7. Makhmud, D. Fatmala, Mewujudkan Kampung Bandan Sebagai Kampung Kota Berkelanjutan Menggunakan Pendekatan Asian New Urbanism, Jurnal Arsitektur, Bangunan, dan Lingkungan. 6(3), 91 - 100 (2017)

8. U.I. Hadri, Pemberdayaan Masyarakat Miskin Dalam Implementasi Proyek Peremajaan Permukiman Kumuh Di Bantaran Sungai Kalianyar Mojosongo, Surakarta : Fakultas Ilmu Sosial dan Politik Universitas Sebelas Maret (2000)

9. M.G. Rindarjono, Subject Mater Geografi Permukiman, Tidak Dipublikasikan (2002)

10. (http://gerbanghebat.semarangkota.go.id/home/haltematik/1, retrieved on January 3, 2019).

11. A.B. Marvati, Qualitative Research in Sociology: An Introduction, Thousand Oaks: sage Publ. Inc (2004)

12. J.W. Creswell, Research Design: Qualitative, Quantitative, and Mixed Methods Approaches, California: Sage Publications, Inc (2008)

13. S. Danim, Menjadi Peneliti Kualitatif, Bandung: PustakaSetia (2002)

14. R. Florida, The Rise of the Creative Class, The Washington Monthly May (2002)

15. C. Landry, The Creative City: A Toolkit of Urban Innovators, London: Earthscan (2008)

16. S. Handayani, Partisipasi Masyarakat Kampung Kumuh dalam Upaya Perbaikan Lingkungan Permukiman, Jurusan Pendidikan Teknik Arsitektur FPTK UPI (2007)

Informants:

\begin{tabular}{|c|c|}
\hline 1. Name & : Luwiyanto \\
\hline Address & : Kampung Batik RT 04, RW 02 \\
\hline Occupation & : Teacher \\
\hline 2. Name & : Dwi Christianto \\
\hline Address & : Kampung Batik RT 04, RW 02 \\
\hline Occupation & : Private employee \\
\hline 3. Name & : Eko Hariyanto \\
\hline Address & : Kampung Batik RT 02,RW 02 \\
\hline Occupation & : Batik entrepreneur \\
\hline
\end{tabular}

4. Name : Iin Windhi Indah Tjahjani

Address : Kampung Batik RT 02,RW 02

Occupation : Batik entrepreneur.
5. Name
: Afifah
Address
: Kampung Batik RT 02,RW 02
Occupation 


$\begin{array}{ll}\text { 6. Name } & \text { : Fauzi } \\ \text { Address } & \text { : Kampung Batik RT 01,RW 01 } \\ \text { Occupation } & \text { : Batik trader. } \\ \text { 7. Name } & \text { : Christine } \\ \text { Address } & \text { : Kampung Batik RT 04,RW 02 } \\ \text { Occupation } & \text { : Batik trader. } \\ \text { 8. Name } & \text { : Ida Purwati } \\ \text { Address } & \text { : Kampung Batik RT 01,RW 02 } \\ \text { Occupation } & \text { : Batik trader. } \\ & \text { : Elizabeth } \\ \text { 9. Name } & \text { : Kampung Batik RT 05,RW 02 } \\ \text { Address } & \text { : Batik trader. }\end{array}$

